\title{
Identification and characterization of viroids in 'Navelina ISA 315' sweet orange
}

\author{
Marcelo Eiras ${ }^{1}$, Simone R. Silva ${ }^{2}$, Eduardo S. Stuchi ${ }^{3,4}$, Sérgio A. Carvalho ${ }^{5}$ \& Renata M. Garcêz \\ ${ }^{1}$ Laboratório de Fitovirologia e Fisiopatologia, Centro de Pesquisa e Desenvolvimento de Sanidade Vegetal, Instituto \\ Biológico, Av. Conselheiro Rodrigues Alves, 1252, 04014-002, São Paulo, SP, Brasil; ${ }^{2}$ Departamento de Produção Vegetal, \\ ESALQ-USP, 13418-900, Piracicaba, SP, Brasil; ${ }^{3}$ Embrapa Mandioca e Fruticultura, 44380-970, Cruz das Almas, BA, Brasil; \\ ${ }^{4}$ Estação Experimental de Citricultura de Bebedouro, 14700-971, Bebedouro, SP; ${ }^{5}$ Centro de Citricultura Sylvio Moreira, \\ Instituto Agronômico de Campinas, 13490-970, Cordeirópolis, SP, Brasil
}

Author for correspondence: Marcelo Eiras, e-mail: eiras@biologico.sp.gov.br

\begin{abstract}
To date, seven species of viroids have been described infecting Citrus. However, only Citrus exocortis viroid (CEVd), Hop stunt viroid (HSVd) and Citrus dwarfing viroid (CDVd) have been reported in this crop in Brazil. The aim of our work was to identify and characterize viroids infecting plants of 'Navelina ISA 315' sweet orange cultivar grafted on 'Rangpur' lime from field experiments located in Bebedouro, SP, that showed gumming in the bark and wood symptoms. Biological indexing was done on the indicator host ' $\mathrm{Clemelin}$ 1120 ' tangor plants that reacted with typical gumming symptoms. Viroid infection was assessed by graft-inoculation of buds from the field trees on 'Etrog' citron plants grafted on 'Rangpur' lime, followed by RNA extraction and sPAGE analysis. RNAs were subjected to RTPCR with primers for citrus viroids. The full-length amplified products were sequenced and compared to those available in the GenBank. The trees were found to be infected with cachexia (Ca) variants of HSVd-Ca or HSVd-Ca plus CDVd. The results indicate that efforts have to be made to increase and stimulate the indexing programs, to maintain plants healthy and to develop sanitary programs focused on reducing the spread of viroids and other graft-transmissible agents.
\end{abstract}

Key words: Citrus, Pospiviroidae, cachexia, hop stunt, pospiviroid, xyloporosis.

Viroids are naked, small, circular, covalently closed, single-stranded RNA pathogens, which infect plants, causing diseases of economic importance in several crops, including Citrus spp. These subviral agents are classified according to their molecular and biological properties into two families: Pospiviroidae and Avsunviroidae. All citrus viroids belong to Pospiviroidae, composed of species with a central conserved region (CCR), without the hammerhead ribozyme activity and that replicate in the nucleus of infected cells (Flores \& Owens, 2008). Citrus are natural hosts of isolates belonging to seven viroid species: Citrus exocortis viroid (CEVd, genus Pospiviroid), Hop stunt viroid (HSVd, Hostuviroid), Citrus bark cracking viroid (CBCVd, Cocadviroid), Citrus bent leaf viroid (CBLVd), Citrus dwarfing viroid (CDVd), Citrus viroid V(CVd-V) and Citrus viroid VI (CVd-VI) of the genus Apscaviroid (http:// www.ictvonline.org/virusTaxonomy.asp). Citrus viroids infect Citrus and plants of closely-related genera, and are usually present as complex viroid mixtures. They are grafttransmitted and propagated by symptomless infected budwood material (Duran-Vila \& Semancik, 2003; Eiras et al., 2010). CEVd and HSVd are the causal agents of two wellknown citrus viroid diseases, exocortis and cachexia (or xyloporosis), respectively. Although some citrus infecting viroids, as CBLVd and CDVd, do not incite conspicuous symptoms, they can reduce tree size and crop yield (Murcia et al., 2009; Vernière et al., 2006). The control of viroids is based on prevention measures, using viroid-free bud-wood as propagation material, appropriate sanitation, treatment of cutting tools and adequate indexing procedures (Duran-Vila \& Semancik, 2003; Eiras et al., 2009).

Citrus-cachexia is known to be caused by the same pathogen of xyloporosis, disease first described as causing trunk wood pitting in 'Palestina' sweet lime (C. limettioides Tanaka), used as rootstock (Reichert \& Perlberger, 1934). The term cachexia was used further in California, USA, for a disease observed in 'Orlando' tangelo (C. paradisi Macf. $\mathrm{x}$ C. tangerina Hort. ex Tan.) causing gumming and browning of phloem tissues, wood pitting and bark cracking (Childs, 1950), but only in 1988 it was demonstrated to be caused by specific variants of HSVd (formerly named Citrus viroid II, CVd-II) (Semancik et al., 1988). The predicted most stable RNA secondary structure of the HSVd (295 to 303 nucleotides in length) is a rod-like conformation with five domains [Terminal Left (TL), Pathogenic (P), Central (C), Variable (V) and Terminal Right (TR)], and Central Conserved Region (CCR) and Terminal Conserved Hairpin (TCH) motifs. HSVd is the only member of the genus Hostuviroid, Pospiviroidae (Flores \& Owens, 2008). To date, two HSVd distinct strains have been reported: (i) "non- 
pathogenic strains" (formerly included as CVd-IIa) that infect sensitive hosts without inducing symptoms; and (ii) "pathogenic strains" (formerly referred as CVd-IIb and CVdIIc) that infect the same sensitive hosts, but inciting cachexia disease. The causal agents of cachexia disease can incite severe gumming, discoloration and wood pitting symptoms in alemow (Citrus macrophylla Webster), clementines (C. clementina Hort. Ex. Tan), mandarins (C. reticulata Blanco), satsumas [C. unshiu (Macf.) Marc.], 'Rangpur' lime (C. limonia Osb.), kumquats (Fortunella spp.) and hybrids like tangelos. The 'Parson's Special' mandarin $(C$. reticulata Blanco) has been used as experimental host for biological indexing to the presence of a cachexia-inducing isolate (Reanwarakorn \& Semancik, 1999). In the HSVd RNA molecule, there are five highly conserved residues ("cachexia expression motif") located both in the upper (3 nucleotides) and the lower (2 nucleotides) strands of the "V" domain that determine the expression of cachexia symptoms (Palacio-Bielsa et al., 2004; Serra et al., 2008). Vernière et al. (2004), in an exhaustive work evaluating the individual effect of each citrus viroid on symptom expression on Clementine trees grafted on trifoliate orange [Poncirus trifoliata (L.) Raf.], confirmed that only CEVd and specific variants of HSVd (CVd-IIb and CVd-IIc) induced exocortis and cachexia, respectively.

In Brazil, xyloporosis was first described in the 1930's, infecting 'Barão' sweet orange [Citrus sinensis (L.) Osb.] grafted on 'Rangpur' lime rootstock, and after detected in 'Pera' sweet orange, 'Mexerica-do-rio' and 'Dancy' mandarins and in 'Red Blush' grapefruit $(C$. paradise Macf.) (Muller \& Costa, 1993). In 2005, Targon et al. characterized viroids infecting grapefruit grafted on trifoliate orange rootstock, from São Paulo state, and detected only the presence of CEVd, CDVd and CVdIIa (non-cachexia) isolates. Only these viroids were also identified in 'Tahiti' acid lime [Citrus latifolia (Yu. Tanaka) Tanaka], in different combinations, in the State of São Paulo (Eiras et al., 2010).

Firstly described in 1948, affecting trees grown on trifoliate orange rootstock, the exocortis is also a graft transmissible disease induced by CEVd. Differently of Cachexia disease, the symptoms of exocortis consist of a bark shelling or scaling disorder, that affects trifoliate orange and its hybrids (Troyer and Carrizo citranges) and 'Rangpur' lime, which are worldwide employed as rootstocks in commercial citrus orchards. When tolerant cultivars are grafted on sensitive rootstocks, bark scaling can be observed in the rootstock and yellowing and general decline on canopy, with economic losses, mainly due to the reduction of the tree size (Duran-Vila \& Semancik, 2003; Eiras et al., 2009). Biologically, it is possible to distinguish the presence of CEVd using 'Etrog' citron (C. medica L.) as indicator host, which reacts with severe leaf epinasty only for CEVd isolates, despite of the recent identification of an unusual CEVd isolate in a symptomless 'Etrog' citron from Colombia (Murcia et al., 2011).
The present work aimed to identify and characterize, by biological and molecular approaches, the viroid species infecting trees of 'Navelina ISA 315' cultivar of sweet orange grafted on 'Rangpur' lime, from field experiments conducted at the Estação Experimental de Citricultura de Bebedouro (EECB), Bebedouro city, State of São Paulo, Brazil, that presented viroid typical symptoms in the field, and during biological indexing.

Samples from the Germplasm Active Bank of 'Navelina ISA 315' trees grafted on 'Rangpur' lime, exhibiting symptoms of wood pitting and gumming of phloem tissue (named Nav1, Nav5 and Nav6) were collected for analysis of viroid infection. Biological indexing was performed by double bud-graft inoculation under greenhouse warm conditions (temperature ranging $32-40^{\circ} \mathrm{C}$ day, $25-30^{\circ} \mathrm{C}$ night) using 'Rangpur' lime as rootstock and 'Clemelin 1120' tangor as indicator. Threesided rectangular cuts were made across the bud-union, the bark was lifted back and the area examined for the typical brown gum-stain symptoms diagnostic for cachexia. For increasing the titer of all citrus viroids in vivo, the use of citron (C. medica L.) as bio-amplification host has been adopted in several indexing programs (Duran-Vila \& Semancik, 2003). Therefore, mixed buds from the field trees were grafted onto 'Etrog' citron plants on 'Rangpur' lime as rootstock. Plants were maintained in a greenhouse with a temperature ranging from 28 to $36^{\circ} \mathrm{C}$ and, sixty days after grafting, citron leaves were collected. The symptoms observed in grafted citrons were either strong leaf curling or no symptoms at all.

Ten grams of young leaves of 'Etrog' citron were ground with liquid nitrogen and homogenized in the presence of a mixture of water-saturated phenol and extraction buffer (125 mM Tris-HCl, pH 9.0, 0.75\% SDS, 15 mM EDTA, $100 \mathrm{mM}$ 2-mercaptoethanol). Total RNA extracted was fractionated by chromatography on non-ionic cellulose CF-11 (Whatman), recovered by ethanol precipitation and resuspended in sterile water. Aliquots of the RNA preparations were separated by electrophoresis in a nondenaturing $5 \%$ gel that was stained with ethidium bromide. A segment of this gel delimited by Avocado sunblotch viroid (ASBVd, $248 \mathrm{nt}$ ) and CEVd (371 nt) RNAs was cut and applied onto a second denaturing 5\% gel that was stained with silver nitrate.

For reverse transcription, couples of adjacent primers derived from each citrus viroid CCR were used according to Eiras et al. (2010). First strand synthesis of the cDNAs was performed at $42^{\circ} \mathrm{C}$ for 1 hour, using 0.25 $\mu \mathrm{g}$ of total RNA and 5 pmol of each complementary primer, with 200 units (U) of M-MLV RT (Promega) and $1 \mathrm{mM}$ dNTPs in the RT buffer recommended by the supplier. PCR was carried out in $50 \mu \mathrm{l}$ using $1 \mu \mathrm{L}$ of the cDNA reaction mixture, 2.5 U of Go Taq flexi DNA polymerase (Promega), 50 pmol of each primer, $0.4 \mathrm{mM}$ of each dNTP, $2.5 \mathrm{mM}$ $\mathrm{MgCl}_{2}$ and the buffer recommended by the supplier. The full-length amplification products (299 bp for HSVd and 
294 bp for CDVd) were cloned, sequenced and compared with viroid sequences in the GenBank. Secondary structure was obtained with mFold program applied to circular RNA and RNAviz program. Multiple sequence alignments and comparisons were performed using the BioEdit (version 7.1.3) program.

Analysis of the bio-amplified RNA preparations extracted from leaves of 'Etrog' citron, previously grafted with buds of 'Navelina ISA 315', by sPAGE showed bands with the characteristic mobility of the circular viroid molecules, absent in the non-inoculated control (data not shown). The results obtained by sPAGE showed that the samples could be single infected by HSVd (Nav1) or doubly-infected by HSVd and CDVd (Nav5 and Nav6), revealed by two patterns of bands observed in the silver nitrate stained gel (Figure 1). To further corroborate their identity, these samples were subjected to RT-PCR, and we have successfully amplified DNA fragments only with specific primers for HSVd (Nav1, Nav5 and Nav6) and for CDVd (Nav5 and Nav6), each one with expected length (299 and 294 for HSVd and CDVd, respectively), confirming our first sPAGE results. Sequence comparisons revealed a high degree of identity to HSVd variants that induce cachexia $(\mathrm{Ca})$ and $\mathrm{CDVd}$ deposited in the GenBank. All three HSVd clones presented 299 nucleotides in length and the TCH motif in the TL domain. In addition, we have identified the five conserved residues located both in the upper (three nucleotides) and the lower (two nucleotides) strands of the $\mathrm{V}$ domain that determine the expression of cachexia symptoms (Palacio-Bielsa et al., 2004; Serra et al., 2008), showed in the white boxes (Figure 2). The predicted rod-like secondary structure of minimum free energy for the HSVd cachexia isolates is represented in Figure 2. The isolates HSVd-Nav5 and -Nav6 showed $100 \%$ of nucleotide identity, and the differences on nucleotide residues found between HSVd-Nav1 and HSVd-Nav5 or -Nav6 are marked in the black boxes: $26(\mathrm{G} \rightarrow \mathrm{A}), 27(\mathrm{G} \rightarrow \mathrm{A}), 29(\mathrm{C} \rightarrow \mathrm{G})$, $30(\mathrm{~A} \rightarrow \mathrm{C}), 53(\mathrm{G} \rightarrow \mathrm{A}), 243(\mathrm{U} \rightarrow \mathrm{G}), 247(\mathrm{~A} \rightarrow \mathrm{G}), 275$ $(\mathrm{G} \rightarrow \mathrm{U}), 277(\mathrm{C} \rightarrow \mathrm{U})$. All residue changes are located in the TL and P domains, in loops that did not alter the molecule structure, or in stems with another substitution that restore base pairing (Figure 2). Sequence analysis and comparisons through the multiple alignment of the three citrus cachexia isolates, characterized in this work, with other $18 \mathrm{HSVd}$ citrus isolates from different countries, and five HSVd isolates from other hosts (almond, grapevine, Prunus and apricot), showed that the HSVd-Nav1, -Nav5 and -Nav6 isolates belong to $\mathrm{CVd}$-IIb (cachexia) group with high percentage (98 to $99 \%$ ) of nucleotide identity among them, confirming our biological results.

The CDVd clones (obtained from Nav5 and Nav6 sources) presented $100 \%$ of nucleotide identity and showed high sequence conservation (97 to $99 \%$ of nucleotide identity) with other CDVd deposited in the GenBank,

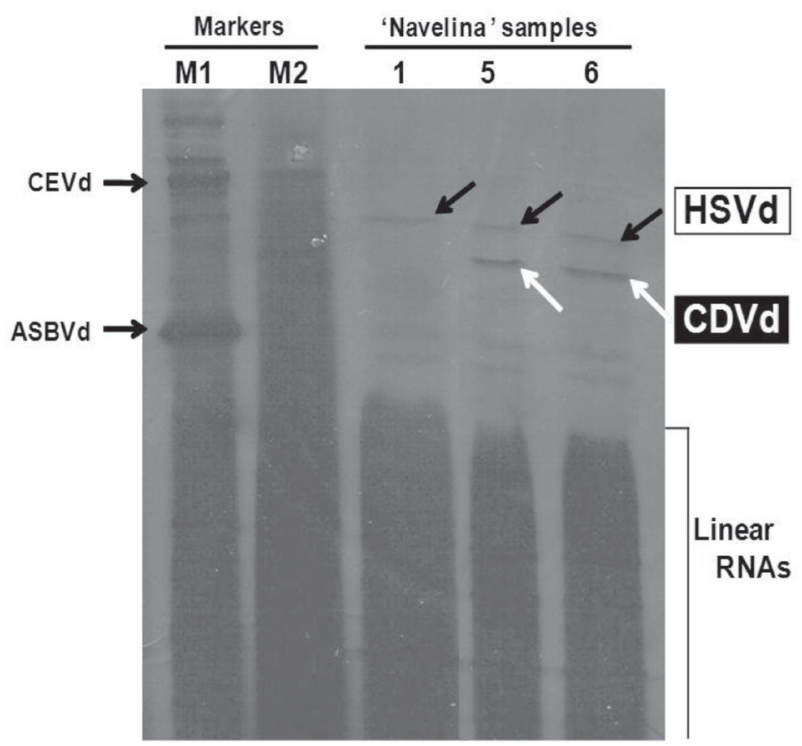

FIGURE 1 - Results of sPAGE of the RNAs extracted from 'Navelina ISA 315' sweet orange samples grafted on 'Etrog' citron: 1 - HSVd (black arrow); 5 and 6 - HSVd (black arrows) plus CDVd (white arrows). Markers: M1 - CEVd (371 bases) + ASBVd (248 bases); M2 - RNA extracted from 'Etrog' citron infected by CEVd.

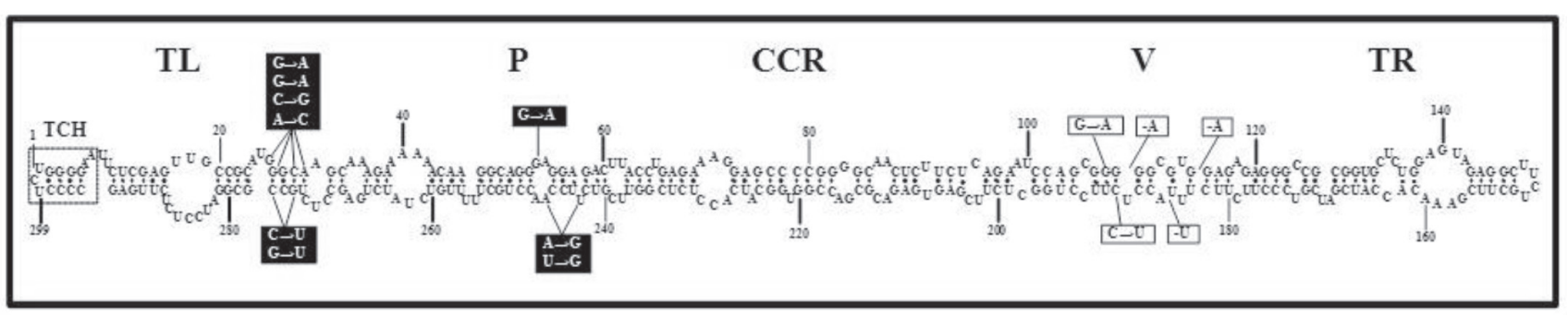

FIGURE 2 - Predicted rod-like secondary structure of minimum free energy (form at $24^{\circ} \mathrm{C}$ by mFold and visualized with RNAviz program) for the HSVd cachexia isolate from 'Navelina ISA 315' sweet orange (HSVd-Nav1) with 299 nucleotides in length. Differences on nucleotide residues found between the isolates HSVd-Nav5 and -Nav6 are marked in the black boxes. The five nucleotide residues which discriminate the cachexia phenotype are indicated in the white boxes. The domains Terminal Right (TR), Variable (V), Central Conserved Region (CCR), Pathogenic (P) and Terminal Left (TL) are indicated, including the boxed motif Terminal Conserved Hairpin (TCH). 
consequence of a low genetic variability of this viroid species, as also observed by Owens et al. (1999), Murcia et al. (2009) and Eiras et al. (2010). We did not observe any differences on symptoms in the plants single (Nav1) or doubly infected (Nav5 and Nav6) by HSVd and CDVd. According to Vernière et al. (2004; 2006), the only visible effect caused by CDVd in single infections is the dwarfing on the infected trees, that has pointed CDVd as the most promising agent to control citrus tree size without inducing other undesirable effect in the plants. However, antagonistic interactions between CEVd and CDVd or CBLVd and CDVd were observed in Clementines trees grafted on trifoliate orange (Vernière et al., 2006). CDVd alone or in combination with a non-cachexia HSVd source also is capable to reduce the tree size (Hutton et al., 2000).

In the field, citrus trees are naturally co-infected with a mixture of viroid species, that can result in antagonistic or synergistic effects depending on viroid species or viroid variants interactions (Vernière et al., 2004; 2006). 'Etrog' citron when co-inoculated with CBLVd, HSVd and CDVd showed a synergistic effect (Duran-Vila et al., 1988), while, conversely, cachexia sources of HSVd co-inoculated with other viroid combinations masked the typical symptoms on the 'Parson's Special' mandarin indicator plants, indicating an antagonistic effect (Pina et al., 1991). It was also demonstrated to occur between cachexia and noncachexia variants of HSVd (Semancik et al., 1992; Elleuch et al., 2004). More recently, in China, Wang et al. (2010) demonstrated that co-infection of non-cachexia HSVd variants interfered in an antagonistic manner with the cachexia HSVd variants, suppressing symptom expression. They also observed that the distribution of CVd-IIb is more widespread than CVd-IIc.

'Navelina ISA 315' cultivar was developed in Italy, in 1976, from a clone recovered in vitro by cultivation of undeveloped ovules. It was introduced in Brazil and established in the field in 2000, as part of the program to search for Citrus variegated chlorosis (CVC) resistance. HSVd causing cachexia has been detected, in this cultivar, by biological indexing (Stuchi et al., 2007) and this infection can be attributed to the collection of buds used in the experiments of dwarfing, induced by viroids inoculation in Italy, reported by Davino et al. (2005). The first suspicion that the 'Navelina ISA 315 ' trees were infected by a cachexia-induced HSVd isolate occurred by the observation of gumming and browning of phloem tissues and wood pitting in the field. After indexing on 'Clemelin 1120' tangor (Carvalho et al., 2003), similar symptoms were observed in all test plants. No reaction was observed after grafting on 'Etrog' citron experimental host.

In Brazil, the 'Navel' sweet orange has a historical importance, because it was originated in the State of Bahia from a mutation in the 'Seleta' sweet orange, which was named as 'Bahia' type (Donadio et al., 1995). In other countries, this and other mutations (such as 'Baianinha') are known as 'Washington Navel'. The navel oranges are among the most appreciated in the world, being grown in the USA, Australia, Spain, Morocco and South Africa. In Brazil, the commercial importance of these varieties decreased with the current prevalence of varieties for juice processing (Donadio et al., 1995). 'Navelina ISA 315' can be considered tolerant to Xylella fastidiosa (causal agent of CVC). Interestingly, seedlings inoculated with $X$. fastidiosa had no symptoms, 18 months after inoculation, in plants with viroids, and in sanitized and pre-immunized plants (Fadel, 2011; Souza et al., 2006; Stuchi et al., 2007).

All HSVd clones sequenced in this study contained the cachexia-associated motif and the corresponding plant sources caused characteristic symptoms when inoculated onto the indicator 'Clemelin 1120' tangor plant. Despite the tolerance of 'Navelina ISA 315' to CVC (Fadel, 2011), there is a need to increase and stimulate indexing programs for maintaining the sanity, and for restriction of the spread of viroids due to its susceptibility to viroids (in special to cachexia variants of HSVd; and to the asymptomatic viroid CDVd).

\section{REFERENCES}

Carvalho SA, Machado MA, Müller GW (2003) Avaliação de indicadoras e porta-enxertos na indexação biológica do viróide da xiloporose em citros. Laranja 24:145-155.

Childs JFL (1950) The cachexia disease of Orlando tangelo. Plant Disease Reporter 34:295-298.

Davino S, Davino M, Caruso A, Sorrentino G, Guardo M, DuranVila N (2005) Performance of Navelina sweet orange on five rootstocks inoculated with citrus viroids. In: $16^{\text {th }}$ Conference of the IOCV, Proceedings... Monterrey Mexico. International Organization of Citrus Virologists. pp. 312-319.

Donadio L, Figueiredo JO, Pio RM (1995) Variedades cítricas brasileiras. Jaboticabal SP. Funep.

Duran-Vila N, Semancik JS (2003) Citrus viroids. In: Hadidi A, Flores R, Randles JW, Semancik JS (Eds.) Viroids. Collingwood Australia. CSIRO Publishing. pp.178-194.

Eiras M, Silva SR, Stuchi ES, Flores R, Daròs JA (2010) Viroids associated with the bark cracking phenotype of 'Tahiti' acid lime in the State of São Paulo, Brazil. Tropical Plant Pathology 35:303309.

Eiras M, Silva SR, Stuchi ES, Targon MLPN, Carvalho SA (2009) Viroides em citros. Tropical Plant Pathology 34: 275-296.

Elleuch A, Marrakchi M, Fakhfakh H, Lévesque D, Perreault JP, Bessais N (2004) Interactions between citrus cachexia viroid and closely related sequence variants may impair expression of cachexia symptoms. Acta Horticulturae 657:401-405.

Fadel AL (2011) Determinação da tolerância da cultivar Navelina ISA 315 à Clorose Variegada dos Citros. MS Dissertation, Universidade Estadual Paulista. Jaboticabal SP.

Flores R, Owens RA (2008) Viroids. In: Mahy BWJ, Van Regenmortel MHV (Eds.) Encyclopedia of Virology, $3^{\text {rd }}$ Ed. Oxford UK. Elsevier. pp. 332-342.

Hutton RJ, Broadbent P, Bevington KB (2000) Viroid dwarfing for 
high density plantings. Horticultural Reviews 24:277-317.

Müller GW, Costa AS (1993) Doenças causadas por vírus viroides e similares em citros. In: Rosseti V. (Ed.) Doenças causadas por algas, fungos, bactérias e vírus. Campinas SP. Fundação Cargill. p.55-84.

Murcia N, Bernad L, Serra P, Bani Hashemian SM, Duran-Vila N (2009) Molecular and biological characterization of natural variants of Citrus dwarfing viroid. Archives of Virology 154:13291334.

Murcia N, Bernad L, Serra P, Duran-Vila N, Serra P (2011) Two nucleotide positions in the Citrus exocortis viroid RNA associated with symptom expression in Etrog citron but not in experimental hosts. Molecular Plant Pathology 12:203-208.

Owens RA, Thompson SM, Feldstein PA, Garnsey SM (1999) Effects of natural sequence variation on symptom induction by citrus viroid III. Annals of Applied Biology 134:73-80.

Palacio-Bielsa A, Romero-Durbán J, Duran-Vila N (2004) Characterization of citrus HSVd isolates. Archives of Virology 149:537-552.

Pina JA, Duran-Vila N, Navarro L (1991) Interference of citrus viroids with cachexia symptoms on Parson's Special mandarin. In: $11^{\text {th }}$ Conference of the IOCV, Proceedings... Orlando FL, USA. International Organization of Citrus Virologists. pp. 206-208.

Reanwarakorn K, Semancik JS (1999) Correlation of hop stunt viroid variants to cachexia and xyloporosis diseases of citrus. Phytopathology 89:568-574.

Reichert I, Perlberger J (1934) Xyloporosis, the new citrus disease. Bulletin of the Agricultural Research Station 12:1-49.

Semancik JS, Gumpf DJ, Bash JA (1992) Interference between viroids inducing exocortis and cachexia diseases of citrus. Annals of Applied Biology 121:577-583.

Semancik JS, Roistacher CN, Rivera-Bustamante R, Duran-Vila N (1988) Citrus cachexia viroid, a new viroid of citrus: relationship to viroids of the exocortis disease complex. Journal of General Virology 69:3059-3068.

Serra P, Gago S, Duran-Vila N (2008) A single nucleotide change in hop stunt viroid modulates citrus cachexia symptoms. Virus Research 138:130-134.

Souza OS, Goes A, Stuchi ES, Jaimes EPG, Wickert E, Silva SR, Donadio LC (2006) Reação de variedades e clones de laranjas a Xylella fastidiosa. Revista Brasileira de Fruticultura 28:145-147.

Stuchi ES, Silva SR, Coletta Filho HD, Franco D, Carvalho AS, Sempionato OR, Donadio LC, Alves KCS (2007) Navelina ISA 315 sweet orange: a citrus variegated chlorosis (CVC) resistant cultivar. In: $17^{\text {th }}$ Conference of the IOCV, Proceedings... Adana Turkey. International Organization of Citrus Virologists. p. 89.

Targon MLPN, Carvalho SA, Stuchi ES, Souza JM, Müller GW, Borges KM, Machado MA (2005) Hybridization techniques for indexing of citrus viroids in São Paulo State, Brazil. Laranja 26:25-38.

Vernière C, Botella L, Dubois A, Chabrier C, Duran-Vila N (2002) Properties of citrus viroids: symptoms expression na dwarfing. In: $15^{\text {th }}$ Conference of the IOCV, Proceedings... Paphos Cyprus. International Organization of Citrus Virologists. pp. 240-248.

Vernière C, Perrier X, Dubois C, Dubois A, Botella L, Chabrier C, Bové JM, Duran-Vila N (2004). Citrus viroids: symptom expression and effect on vegetative growth and yield of clementine trees grafted on trifoliate orange. Plant Disease 88:1189-1197.

Wang X, Zhou Y, Li Z, Tang K, Liu Y, Cao M, Zhou C (2010) Molecular, biological and phylogenetic analysis of Chinese isolates of Hop stunt viroid associated with Cachexia disease. Journal of Phytopathology 158:372-377.

TPP 457 - Received 9 December 2011 - Accepted 3 October 2012 Section Editor: Alice K. Inoue-Nagata 